\title{
44-дневная война: крах оккупационной политики Армении, восстановление территориальной целостности Азербайджана и новая региональная реальность
}

14 -дневная война (27 сентября - 9 ноября 2020) положила конец почти 30-летней территории Азербайджанской Республики.

Части ВС Армении, дислоцированные на оккупированных землях Азербайджана, утром 27 сентября 2020 года начали очередной масштабный обстрел из крупнокалиберного оружия, артиллерии и минометов позиций азербайджанской армии и прифронтовых населенных пунктов Азербайджана. В результате, погибли мирные жители и военнослужащие, серьезно пострадала гражданская инфраструктура. По приказу Верховного главнокомандующего, президента Ильхам Алиева, Вооруженные силы Азербайджана развернули контрнаступательную операцию «Железный кулак» по всему периметру фронта с целью освобождения территорий страны от армянской оккупации. Уже в первые дни военных действий были освобождены несколько сел и ряд стратегических высот, стало очевидно, что азербайджанская армия значительно превосходит армянскую армию как по боевой выучке и моральному духу, так и по качеству вооружения и техническому оснащению. ВC Азербайджана удалось прорвать глубокоэшелонированную оборону армянских оккупационных войск в южной части фронта. Один за другим оккупированные города и селения возвращались под контроль Азербайджана и его Вооруженных сил.

Государства-сопредседатели Минской группы ОБСЕ (США, Россия, Франция), ранее на протяжении многих лет своей посреднической деятельности не предпринявшие кардинальных шагов для принуждения Армении к отказу от военной агрессии против Азербайджана, пресечения оккупации в соответствии с резолюциями Совета Безопасности ООН, принципами и нормами международного права, с самого начала 44-дневной войны предпринимали усилия для объявления перемирия. В условиях разрастания широкомасштабных военных действий между 
Азербайджаном и Арменией особенно в двусмысленном положении оказалась Россия. С одной стороны, она в качестве союзницы Армении как на двусторонней основе, так и в рамках Организации Договора о коллективной безопасности (ОДКБ), должна была оказать ей военную поддержку. С другой, Россия не была заинтересована в ухудшении отношений с Азербайджаном как своим стратегическим партнером и, тем более, во вступлении в войну против него. Но главное - и эту позицию Москвы четко обозначил президент РФ Владимир Путин, - у России не было правовых оснований вступать в войну на стороне своей союзницы, Армении, поскольку боевые действия шли на международно-признанной территории Азербайджана.

Путин, в частности, подчеркнул, что у России есть «определенные обязательства» перед Арменией как членом ОДКБ. «Но боевые действия ведутся не на территории Армении. Что же касается исполнения Россией своих договорных обязательств, то мы всегда исполняли, исполняем и будем исполнять свои обязательства». ${ }^{543}$ Действительно, Россия, как впоследствии признался Путин, продолжала оказывать Армении внушительную помощь отправкой вооружения. «Российская Федерация в рамках и многосторонних, и двусторонних обязательств, в том числе в сфере военнотехнического сотрудничества, полностью выполняла все свои обязательства, за что руководство Армении, в том числе в лице премьер-министра Никола Пашиняна, неоднократно выражало слова благодарности», - заявил Путин. ${ }^{544}$

Одновременно в ходе войны Россия предпринимала усилия и на дипломатическом поприще, добиваясь прекращения огня и объявления перемирия между воюющими сторонами. 9-10 октября в Москве главами МИД Азербайджана и Армении Джейхуном Байрамовым и Зограбом Мнацаканяном было согласовано гуманитарное перемирие. Воюющие стороны договорились прекратить огонь с полудня 10 октября «в гуманитарных целях для обмена военнопленными и другими удерживаемыми лицами и телами погибших при посредничестве и в соответствии с критериями Международного Комитета Красного Креста». Кроме того, была достигнута договоренность между Азербайджаном и Арменией приступить при посредничестве сопредседателей МГ ОБСЕ «К субстантивным переговорам с целью скорейшего достижения мирного урегулирования». 545

\footnotetext{
${ }^{543}$ https://www.rbc.ru/politics/07/10/2020/5f7d773a9a7947642575d8fd

544 https://www.interfax.ru/russia/737570

${ }^{545}$ https://www.mid.ru/foreign_policy/news/-/asset_publisher/cKNonkJE02Bw/content/id/4377041
} 
Однако перемирие, достигнутое при содействии России, продлилось не более суток. Уже 11 октября Вооруженные силы Армении нанесли ракетный удар по второму по величине и значимости городу Азербайджана - Гяндже. Погибли 10 человек, 40 получили ранения. Этот очередной ракетный обстрел Гянджи привел к возобновлению полномасштабных военных действий.

Помимо российской попытки добиться прекращения огня между Азербайджаном и Арменией, были предприняты еще две, при посредничестве западных сопредседателей МГ ОБСЕ - Франции и США. Однако эти попытки, ознаменовавшиеся объявлением гуманитарного перемирия соответственно 17 октября и 26 октября, также оказались неудачными из-за нарушения Арменией достигнутых договоренностей.

17 октября Гянджа вновь подверглась ракетному удару с территории Армении. Погибли 15 мирных жителей, включая детей и подростков, 55 получили ранения. В целом, Гянджа - второй крупный город Азербайджанской Республики, с населением в полмиллиона человек, расположенный более чем в 100 км от зоны боевых действий, неоднократно, 4, 8, 11 и 17 октября, был подвергнут ракетным обстрелам со стороны ВС Армении, в результате которых погибли 32 мирных жителя, 143 получили ранения.

27 октября армянская армия применила запрещенные международным правом кассетные бомбы при ракетном обстреле города Барда, расположенного вдали от линии фронта. Погибли 5 человек, в том числе и один ребенок, ранения получили 13 человек. 28 октября армянская армия во второй раз обстреляла Барду. Кассетные бомбы унесли жизни 21 мирного жителя, почти 70 человек были ранены.

Однако со стороны государств-сопредседателей Минской группы не прозвучало ни одного осуждения в адрес Армении, совершавшей в дни войны преступления против человечности, подвергая ракетным бомбардировкам мирные города и села Азербайджана. ВС Армении целенаправленно наносили удары по мирному населению и гражданской инфраструктуре целого ряда азербайджанских городов, таких как Гянджа, Барда, Тертер, Нафталан, Мингячевир, Агджабеди. Причем обстрелы районных центров Тертерского, Агджабединского и Гёранбойского районов, с применением запрещенных и чрезвычайно опасных бомб с кассетными боеприпасами, практически не прекращались ни на один день в ходе войны. Это была тактика устрашения и террора, аналогичная военным преступлениям, совершенным армянской стороной в период Первой Карабахской войны, только на этот раз при массовом убийстве мирного населения Азербайджана применялись современные типы 
вооружений и ракетных установок большой разрушительной силы, запрещенные международными конвенциями кассетные и фосфорные боеприпасы.

Факты применения армянской стороной ракет «Скад» и «Смерч» не только на поле боя, но и против мирных жителей Азербайджана были признаны международными организациями Human Rights Watch и Amnesty İnternational как «жестокие и безрассудные». В частности, Amnesty International зафиксировала факты обстрела жителей Гянджи артиллерийскими устройствами с использованием баллистических ракет, а также факт обстрела Бардинского района кассетными бомбами. ${ }^{546}$

Таким образом, Армения в ходе 44-дневной войны совершила военные преступления, приведшие к многочисленным жертвам среди мирного населения азербайджанских прифронтовых сел и городов, намного удаленных от зоны боевых действий, и этот факт отражен в отчетах международных правозащитных организаций. По данным Генеральной прокуратуры Азербайджана, за период с 27 сентября 2020 года по 16 ноября 2020 года, в результате преступлений вооруженных сил Армении против мирного населения Азербайджана погибли 94 человек, 414 человек получили ранения. Кроме того, в непригодное для жилья состояние пришли 3410 домов и 120 многоквартирных жилых зданий, а также 512 гражданских объектов. ${ }^{547}$

В связи с этими фактами стоит особо подчеркнуть, что азербайджанская армия ни разу не наносила удары по мирному армянскому населению. На это неоднократно указывал и президент Азербайджана Ильхам Алиев. Так, отвечая на вопрос корреспондента украинского телеканала «Интер» в ходе пресс-конференции для представителей местных и зарубежных СМИ, состоявшейся 26 февраля 2021 года, глава азербайджанского государства отметил минимизацию потерь среди мирного населения. «Это была одна из установок, которые я как Верховный главнокомандующий давал, когда мы осуществляли освободительные действия. Если вы посмотрите на статистику, то, по нашим данным, среди мирного населения противной стороны потери были минимальные. Это менее 40 человек, исходя из того, что среди их военнослужащих, по самым скромным оценкам, потери были где-то 6,5 - 7 тысяч человек. И к тому же еще, с учетом наших наблюдений и фактов, большая часть так называемого мирного населения со стороны противника погибла в то время, когда

\footnotetext{
${ }^{546}$ https://www.hrw.org/news/2020/12/11/armenia-unlawful-rocket-missile-strikes-azerbaijan\#

${ }^{547}$ https://story.karabakh.center/ru/karabakh-eto-azerbaidzhan
} 
они осуществляли действия, связанные с военными действиями: они там были около артиллерийских орудий, подносили боеприпасы, и когда мы эти орудия уничтожали, они просто страдали. Поэтому мирное армянское население в войне не пострадало. К сожалению, армянская сторона, наоборот, стремилась максимально нанести ущерб мирному населению, и бомбардировки Гянджи баллистическими ракетами, и Барды, и Тертера, и других городов об этом говорят», - подчеркнул Ильхам Алиев ${ }^{548}$.

Ильхам Алиев, принимая 12 декабря 2020 года сопредседателей Минской группы ОБСЕ - от Франции Стефана Висконти, от США Эндрю Шофера, а также чрезвычайного и полномочного посла России в Азербайджане Михаила Бочарникова и личного представителя действующего председателя ОБСЕ Анджея Каспшика, подчеркнул: «В многочисленных интервью международным медиа во время войны я говорил, что у нас нет проблем с армянским народом. Наша война с оккупантами, преступниками, захватившими нашу территорию. Армяне же могут жить в условиях безопасности и достойно, как живут сегодня в различных регионах нашей страны. Под нашим управлением улучшится и их благосостояние. После войны мы видим состояние сел, в которых раныше жили армяне. Там царила нищета. Люди жили там в неимоверных условиях. В чем же была цель этой оккупации? Почему армяне на протяжении многих лет содержали там представителей своего народа как рабов? Не знаю, видели вы или нет, в первые дни войны, когда Азербайджанская армия захватила окопы армянской армии, то стала свидетелем того, что некоторые из уничтоженных оккупантов прикованы друг к другу цепями. Это были шокирующие видео. То есть, они вынуждали людей стоять в окопах. Таким образом они останавливали тех, кто пытался бежать, покинуть позиции. Во время войны у них были специальные группы, которые, находясь в тылу армянских войск, убивали пытавшихся бежать представителей своей же нации. Такое случалось часто. Они - военные преступники. Обстрел Гянджи баллистической ракетой, обстрел Барды и Тертера кассетными и фосфорными бомбами, незаконное заселение оккупированных территорий - все это военные преступления, и они гордились этим...». ${ }^{549}$

Однако в ходе войны сопредседателей больше волновали не военные преступления армянских оккупантов, а геополитические последствия неизбежной

\footnotetext{
${ }^{548} \mathrm{https} / / /$ azertag.az/ru/xeber/Prezident_Ilham_Aliev_provel_press_konferenciyu_dlya_predstavitelei_mestnyh_i zarubezhnyh_SMI_OBNOVLENO_7_VIDEO-1722283

${ }^{549} \mathrm{https}: / / \mathrm{moscow}-$

baku.ru/news/politics/ilkham_aliev_prinyal_posla_rossii_i_sopredsedateley_mg_obse_ot_ssha_i_frantsii/
} 
победы Азербайджана. К примеру, после провала американской инициативы о прекращении огня между Азербайджаном и Арменией бывший сопредседатель МГ ОБСЕ от США Керри Кавано выступил со статьей в британском издании Financial Times, в которой призвал к активизации дипломатических усилий России, США и Франции. Он заявил также о своей обеспокоенности в связи с тем, что Турция, являющаяся союзником Азербайджана, и Россия, являющаяся союзником Армении, «вполне могут вступить в бой» 550 .

Между тем, как показал последующий ход событий, Россия и Турция согласовали недопущение своего прямого вмешательства в войну между Азербайджаном и Арменией. Тогда как успешное продвижение азербайджанской армии не оставляло сомнений в том, что война может остановиться только при выполнении Ереваном главного требования Баку - согласия на вывод армянских войск с оккупированных территорий. Примечательна была реакция Баку на оказываемое на него давление в целях приостановления войны без получения от Еревана подтвержденного международными посредниками согласия на вывод армянских войск с территории Азербайджана. Президент Азербайджана Ильхам Алиев твердо дал понять, что контрнаступление азербайджанской армии не остановится до полного прекращения оккупации, и если внешние силы, которые обеспокоены перспективой надвигающегося сокрушительного разгрома Армении, действительно, волнует ее судьба, то пусть они принудят правительство Пашиняна принять единственно спасительное для его страны решение - вывод войск с территории Азербайджана. ${ }^{551}$

Решающим событием Второй Карабахской войны, получившей название 44дневной войны, стало освобождение азербайджанской армией города Шуша. Ввиду того, что Шуша, считающаяся сердцем Карабаха, благодаря рельефу местности является естественным укреплением, войти в город на танках или с помощью прочего тяжелого оружия было невозможно. Имелось только два пути ее освобождения. В первом случае можно было бы уничтожить силы противника, размещенные в городе, артиллерийским огнем и ударами с воздуха, однако командование отказалось от этого варианта, потому что бомбардировка города привела бы к большим разрушениям.

\footnotetext{
${ }^{550}$ Carey Cavanaugh. Nagorno-Karabakh conflict is heading to the point of no return. https://www.ft.com/content/f8f188c3-ef5d-427b-8c11-3850fa3da42d

${ }^{551}$ Натиг Назимоглу. Губадлинский перелом: крушение иллюзорных надежд Армении. https://ru.oxu.az/politics/435011?fbclid=IwAR3RXVTVcuZx33rvzxyWfh01Iqt6_2TYFRgpfx0vXH132iKNjy3b hji-8Kw
} 
Поэтому в качестве альтернативного варианта была выбрана тактика рукопашного боя. Легковооруженные солдаты и офицеры Азербайджанской армии, перебравшись через густые леса, глубокие ущелья, скалы и горы, уничтожали врага в рукопашном бою. Один из зарубежных журналистов, находившийся в то время в Ханкенди, так описывал незавидное положение армян: «Армянская армия в Шуше разгромлена. Десятки раненых на военных машинах скорой помощи транспортируются в больницу в Ханкенди. Остальные военнослужащие, измотанные, спускаются вниз по горам, снимая с себя и сбрасывая вдоль дороги военную форму. Без конца приезжают и уезжают машины скорой помощи. В автомобилях раненые солдаты уложены прямо друг на друга. Травмы, которые они получили, являются доказательством того, что имел место рукопашный бой». В другом репортаже, опубликованном в те дни изданием Le Monde, говорилось, что поверженные военнослужащие армянской армии, получив ранения разной степени, покидают Шушу и бегут в Ханкенди. 8 ноября Верховный главнокомандующий Ильхам Алиев сообщил народу весть об освобождении города Шуша. Победа в Шуше, по сути, предрешила исход войны. На следующий день пришло известие об освобождении еще более чем 70 сел, а днем позже Пашинян был вынужден подписать акт капитуляции, приняв условия президента Азербайджана. ${ }^{552}$

Война завершилась победой Азербайджана, восстановлением его территориальной целостности. Точку же в ней поставило Трехстороннее заявление, подписанное президентом Азербайджана Ильхамом Алиевым, премьер-министром Армении Николом Пашиняном и президентом России Владимиром Путиным в ночь с 9 на 10 ноября 2020 года. Согласно Трехстороннему заявлению, объявлялось полное прекращение огня и всех военных действий в зоне конфликта с 10 ноября 2020 года. Армения мирным путем возвращала Азербайджану его неосвобожденные в ходе войны территории - Агдамский, Кельбаджарский и Лачинский районы. Документ предусматривал, что вдоль линии соприкосновения в Нагорном Карабахе и вдоль Лачинского коридора развертывается миротворческий контингент Российской Федерации в количестве 1960 военнослужащих со стрелковым оружием, 90 бронетранспортеров, 380 единиц автомобильной и специальной техники. Причем миротворческий контингент развертывается параллельно с выводом армянских вооружённых сил. Срок пребывания миротворческого контингента РФ -5 лет с автоматическим продлением на очередные 5-летние периоды, если ни одна из сторон

\footnotetext{
${ }^{552}$ https://www.virtualkarabakh.az/ru/post-item/52/2871/ikinci-qarabag-muharibesi.html
} 
не заявит за 6 месяцев до истечения срока о намерении прекратить применение данного положения. В целях повышения эффективности контроля за выполнением сторонами конфликта договоренностей предусматривалось развертывание миротворческого центра по контролю за прекращением огня.

Согласно Трехстороннему заявлению, Азербайджан гарантирует безопасность движения по Лачинскому коридору граждан, транспортных средств и грузов в обоих направлениях. А Армения гарантирует безопасность транспортного сообщения между западными районами Азербайджана и его Нахчыванской Автономной Республикой с целью организации беспрепятственного движения граждан, транспортных средств и грузов в обоих направлениях. Контроль за этим транспортным сообщением осуществляют органы Пограничной службы ФСБ России.

Документ предусматривал возвращение на территорию Нагорного Карабаха и прилегающих районов внутренне перемещенных лиц и беженцев под контролем Управления Верховного комиссара ООН по делам беженцев. Кроме того, производился обмен военнопленными, заложниками и другими удерживаемыми лицами и телами погибших.

Одно из важнейших положений заявления - разблокирование всех экономических и транспортных связей в регионе, а также обеспечение строительства новых транспортных коммуникаций, связывающих Нахчыванскую Автономную Республику с западными районами Азербайджана. ${ }^{553}$

Таким образом, по результатам войны, длившейся 44 дня, Вооруженные силы Азербайджана нанесли сокрушительное поражение армянской оккупационной армии, разгромив и фактически уничтожив ее. Армения капитулировала, что стало логическим следствием политики агрессии, которую она проводила в отношении Азербайджана почти 30 лет, удерживая под оккупацией 20 процентов азербайджанской территории. Не пожелав в свое время миром решать конфликт с соседями, добровольно вывести свои вооруженные силы с территорий Азербайджана, она получила сокрушительный удар на поле карабахской войны.

Между тем, широкомасштабное контрнаступление Вооруженных Сил Азербайджана знаменовалось крахом агрессивной Армении не только на поле боя. Столь же мощен и убедителен был удар, нанесенный в самую сердцевину стратегической доктрины Армении, коей долгие 27 лет обрабатывалось общественное

\footnotetext{
${ }^{553}$ http://kremlin.ru/events/president/news/64384; http://en.kremlin.ru/events/president/news/64384
} 
мнение в этой стране. Если проанализировать все «вещественные доказательства» армянской политической мысли за последнюю четверть века, то можно прийти к выводу о несоответствующей действительности самооценке Армении, уверовавшей в свою полнейшую безнаказанность за оккупацию части международно-признанной территории Азербайджана, военные преступления против азербайджанского народа. «Непобедимая армянская армия», «Армения - ключевое звено региональной и глобальной геополитики», «Великие державы зависят от Армении», «В руках Армении - судьба цивилизации»... Таков неполный список пропагандистских клише, коими были напичканы мозги армянских обывателей все годы существования статускво в регионе карабахского конфликта - статус-кво, сложившегося в результате военной агрессии Армении, оккупации ею азербайджанских территорий при прямой военной, политической и финансовой поддержке третьих стран. Азербайджанская армия разрушила пресловутый статус-кво, а заодно с ним и все продукты мифотворчества армянских стратегов. Нет «непобедимой армянской армии», она не сумела предовтратить крах захватнической политики Армении, наделившей себя правом на оккупацию чужих территорий, уничтожение и изгнание с этих земель сотен тысяч мирных людей только за то, что они - азербайджанцы...

Но вместо того, чтобы сейчас признать свое поражение и неправоту, Армения не придумала ничего лучше, кроме как пытаться убедить весь мир в том, что, дескать, это «не Азербайджан одолел нас, непобедимых, а орды ведомых турками террористов». Между тем, правда, какой бы горькой она ни была для армянских оккупантов, заключается в том, что их военную агрессию успешно пресекла армия Азербайджана мощные Вооруженные Силы нашего государства, доказавшего, в отличие от «форпоста России на Южном Кавказе», свою полную состоятельность и самодостаточность как во всех направлениях мирного развития, так и на поле боя. Именно азербайджанская армия поставила на колени оккупационные войска Армении, именно от азербайджанской армии они получили сокрушительные удары с тем, чтобы после этого, как подчеркнул Президент Азербайджана Ильхам Алиев, им «неповадно было даже смотреть в нашу сторону».

Армянская риторика о якобы поддерживающих Азербайджан террористах не выдерживала никакой критики и оттого, что терроризм - излюбленная стезя самой Армении и армянских националистов. Боевики из ASALA, «Дашнакцутюна» и других армянских террористических организаций, равно как и курдских, арабских и других этно-террористических группировок, стали последней надеждой агонизирующей в ходе 
44-дневной войны армии Армении. Надежды, впрочем, бессмысленной и заведомо обреченной на полный провал. Не зря президент Ильхам Алиев, констатировав факт размещения в Армении и на оккупированных территориях Азербайджана террористических лагерей, предупредил в ходе войны, что после освобождения Карабаха в живых там не останется ни один террорист. ${ }^{554}$

Таким образом, Армения потерпела тотальное поражение, что и нашло свое отражение в акте о ее капитуляции - Трехстороннем заявлении от 10 ноября 2020 года. Гарантом же данного азербайджано-армянского соглашения, подведшего черту под 44дневной войной, по сути стала Россия. Но в то же время в качестве одной из миротворческих сил выступила и Турция. Мировые СМИ обратили особое внимание на озвученные президентом Азербайджана в момент подписания Трехстороннего заявления в онлайн-режиме слова о том, что Турция также примет участие в миротворческом процессе. ${ }^{555}$

Действительно, уже на следующий день после подписания Трехстороннего заявления, 11 ноября, по итогам переговоров по видеосвязи министров обороны России и Турции - Сергея Шойгу и Хулуси Акара - был подписан Меморандум о создании совместного российско-турецкого Центра по контролю за прекращением огня в Нагорном Карабахе. ${ }^{556}$

Таким образом, в результате 44-дневной войны в регионе Южного Кавказа сложилась новая геополитическая реальность. Ее основу составляет стратегическое сотрудничество между Россией и Турцией при значительно усилившихся региональных позициях Азербайджана, победа которого в войне с Арменией закрепила его в роли государства-лидера Южного Кавказа.

Москва и Анкара предпринимают совместные мирные усилия в рамках деятельности российско-турецкого Центра по контролю за прекращением огня, построенного в освобожденном от армянской оккупации Агдамском районе Азербайджана. При этом Россия и Турция рссматривают в качестве двигателя мирного процесса экономическую интеграцию, разблокирование существующих и создание

\footnotetext{
554 Натиг Назимоглу. Как азербайджанские солдаты развенчивают миф о «непобедимой армянской армии». https://media.az/politics/1067795130/vooruzhennye-sily-azerbaydzhana-krushat-okkupantov-i-mif-onepobedimoy-armyanskoyarmii/?fbclid=IwAR0dafyfwxUrbvMbMYs474r9or4fJ1BSUhH4gDQHD2JNKo1qF6zgErZz0V8

${ }^{555}$ Armenia, Azerbaijan and Russia sign Nagorno-Karabakh peace deal. https://www.bbc.com/news/worldeurope-54882564

${ }^{556} \mathrm{https} / / / \mathrm{www}$. interfax.ru/world/736700
} 
новых транспортных коммуникаций в регионе. Сотрудничество Москвы и Анкары можно считать одним из краеугольных камней платформы шестистороннего сотрудничества на Южном Кавказе, с инициативой создания которого выступили президенты Азербайджана и Турции - Ильхам Алиев и Реджеп Тайип Эрдоган.

Платформа «3+3» предполагает развитие многостороннего сотрудничества в самых разных сферах - политики, безопасности, экономики и т.д. - с участием трех южнокавказских государств - Азербайджана, Грузии, Армении, а также их трех крупных соседей - России, Турции, Ирана. Участие Армении в этом общерегиональном проекте мира и сотрудничества лежит через признание ею территориальной целостности Азербайджана и Турции, а также содействие разблокированию транспортных сообщений, прописанному в трехсторонних заявлениях лидеров Азербайджана, России и Армении - не только от 10 ноября 2020 года, но и 11 января 2021 года.

В рамках сложившегося в заключительный день войны трехстороннего формата постконфликтного мирного процесса - Азербайджан-Армения-Россия - Москва инициировала подписание еще одного документа, с уклоном на налаживание сотрудничества между Баку и Ереваном. Подписанное в российской столице Трехстороннее заявление от 11 января 2021 года явилось как бы продолжением заявления от 10 ноября 2020 года. В новом документе нашла свое отражение договоренность лидеров Азербайджана, Армении и России о создании на основе предложения президента РФ Путина трехсторонней Рабочей группы под совместным председательством вице-премьеров Азербайджана, Армении и России. В качестве приоритетов деятельности Рабочей группы были определены железнодорожное и автомобильное сообщение, а также иные направления сотрудничества между тремя государствами. В качестве задач, поставленных перед Рабочей группой, было обозначено, в частности, «восстановление и сооружение новых объектов транспортной инфраструктуры, необходимых для организации, выполнения и обеспечения безопасности международных перевозок, осуществляемых через Азербайджанскую Республику и Республику Армения, равно как и перевозок, осуществляемых Азербайджанской Республикой и Республикой Армения, при выполнении которых требуется пересечение территорий Азербайджанской Республики и Республики Армения». 557

\footnotetext{
${ }^{557}$ http://www.kremlin.ru/supplement/5606
} 
В соответствии с Трехсторонним заявлением от 11 января периодически проводятся встречи между вице-премьерами Азербайджана, Армении и России. Несмотря на очевидные сложности в установлении поствоенного мира, Россия, разместившая свой миротворческий контингент в некоторых местностях в горной части Карабахского региона Азербайджана, декларирует необходимость полного выполнения всех пунктов трехсторонних заявлений. Так, глава МИД РФ Сергей Лавров, посетив Ереван и Баку в мае 2021 года, подтвердил безальтернативность экономического разблокирования как основы мирного процесса между Азербайджаном и Арменией. Кроме того, он выступил за решение «гуманитарных проблем», включая и предоставление Арменией карт минных полей Азербайджану. Последнее позволит активизировать ход восстановительных работ на освобожденных от армянской оккупации территориях и предотвратит вероятность все новых смертей от взрывов мин.

В позиции России обращает на себя внимание отсутствие каких-либо веских заявлений о «статусе Нагорного Карабаха» - потерявшем актуальность вопросе, который армянская сторона периодически пытается «протолкнуть» на площадке своих обсуждений с западными сопредседателями Минской группы ОБСЕ. Сразу по окончании войны президент России Путин выразил надежду на то, что «мы уже не будем употреблять это словосочетание - «нагорно-карабахский конфликт». ${ }^{558} \mathrm{~B}$ одном из своих последующих заявлений Путин подтвердил, что «территория Нагорного Карабаха с позиций международного права является частью Азербайджана». ${ }^{59}$

Завершение нагорно-карабахского конфликта провозгласил президент Азербайджана Ильхам Алиев. В истории Азербайджана и всего региона начался постконфликтный период, одной из важнейших характеристик которого является возрождение Карабаха, масштабное восстановление освобожденных территорий, разрушенных и разграбленных за 30-летний период армянской оккупации азербайджанских городов и селений. Показательны слова Ильхама Алиева: «Мы восстановим и дома, и природу». И, как подтверждение этого, стартовавшие работы по восстановлению не только городов и селений, но и природных заповедников, которые долгие годы подвергались уничтожению, экологическому террору со стороны оккупантов.

\footnotetext{
${ }^{558} \mathrm{http}: / /$ kremlin.ru/events/president/news/64409

${ }^{559} \mathrm{https}: / /$ tass.ru/politika/10283731
} 
Освобожденные города и села восстанавливаются на основе генерального плана. Приоритетной целью обозначено скорейшее возвращение сотен тысяч вынужденных переселенцев на свои родные земли. Президент Ильхам Алиев заявил в этой связи: «Для возвращения граждан в родные края со стороны государства будет оказана необходимая помощь. ${ }^{560}$ Ему же принадлежит высказывание, точно определяющее суть наступившего по завершении 44-дневной войны исторического момента: «Мы вернулись на эти земли. Мы вернулись как героический народ, как государствопобедитель. Мы изгнали врага с родных земель. Мы восстановим все наши разрушенные города и села, жизнь вернется, люди вернутся, и мы еще раз продемонстрируем всему миру величие нашего народа. Сейчас начинается новый период нашей жизни - период созидания, развития, восстановления наших земель» ${ }^{561}$.

\section{Streszczenie:}

44-dniowa wojna (27 września 2020 r. - 9 listopada 2020 r.) położyła kres prawie 30letniej okupacji jednej piątej terytorium Republiki Azerbejdżanu przez Armenię. Siły zbrojne Azerbejdżanu przywróciły integralność terytorialną swojego państwa. W czasie wojny Armenia popełniła nowe zbrodnie wojenne na ludności Azerbejdżanu. Wśród nich - ataki rakietowe na Ganję, Bardę i inne miasta Azerbejdżanu, które doprowadziły do licznych ofiar wśród ludności cywilnej. Zwycięstwo Azerbejdżanu umocniło jego pozycję jako lidera Kaukazu Południowego i stworzyło nową rzeczywistość regionalną, w której ważną rolę odgrywa współpraca pokojowa między Rosją a Turcją.

\section{Słowa kluczowe:}

Azerbejdżan, Armenia, wojna, integralność terytorialna, ludność cywilna, ostrzał, ofiary, Ganja, Barda, region, rzeczywistość, Kaukaz Południowy, Rosja, Turcja.

\section{Key words:}

Azerbaijan, Armenia, war, territorial integrity, civilian population, shelling, victims, Ganja, Barda, region, reality, South Caucasus, Russia, Turkey.

\section{Bibliografia:}

1. Armenia, Azerbaijan and Russia sign Nagorno-Karabakh peace deal, https://www.bbc.com/news/world-europe-54882564

2. Carey Cavanaugh. Nagorno-Karabakh conflict is heading to the point of no return. https://www.ft.com/content/f8f188c3-ef5d-427b-8c11-3850fa3da42d

\footnotetext{
${ }^{560}$ https://www.virtualkarabakh.az/ru/post-item/52/2871/ikinci-qarabag-muharibesi.html

${ }^{561}$ https://karabakh.center/d/page18485477.html
} 
3. Натиг Назимоглу. Губадлинский перелом: крушение иллюзорных надежд Армении.https://ru.oxu.az/politics/435011?fbclid=IwAR3RXVTVcuZx33rvzxyWfh0 1Iqt6_2TYFRgpfx0vXH132iKNjy3bhji-8Kw

4. Натиг Назимоглу. Как азербайджанские солдаты развенчивают миф о «непобедимой армянской армии».

https://media.az/politics/1067795130/vooruzhennye-sily- azerbaydzhana-krushatokkupantov-i-mif-o-nepobedimoy-armyanskoyarmii/?fbclid=IwAR0dafyfwxUrbvMbMYs474r9or4fJ1BSUhH4gDQHD2JNKo1qF6z gErZz0V8

5. www.azertag.az

6. www.interfax.ru

7. www.interfax.ru

8. www.karabakh.center

9. www.kremlin.ru

10. www.mid.ru

11. www.rbc.ru

12. www.tass.ru

13. www.virtualkarabakh.az

14. www.virtualkarabakh.az 